\title{
Microautoradiography-based enumeration of photosynthetic picoplankton with estimates of carbon-specific growth rates
}

\author{
Donald J. Douglas \\ Department of Oceanography, Dalhousie University, Halifax, Nova Scotia B3H 4J1, Canada
}

\begin{abstract}
A method based on autoradiography and epifluorescent microscopy of cell samples incubated with $\mathrm{H}^{14} \mathrm{CO}_{3}$ was used to detect and enumerate phototrophic microorganisms. The picoplankton cells which fixed $\mathrm{H}^{14} \mathrm{CO}_{3}$ in the light were spherical or ovoid and ranged from 0.8 to $1.4 \mu \mathrm{m}$ in maximum dimension. Photosynthetic picoplankton abundance ranged from 3.7 to $49 \times 10^{6}$ cell $1^{-1}$ at 5 stations selected to provide a wide range of environmental conditions. Primary production of the $\leq 1.0 \mu \mathrm{m}$ fraction, as estimated by ${ }^{14} \mathrm{C}$ uptake, amounted to $12.7 \%$ to $65.1 \%$ of total particulate production. Cell abundance estimates combined with data from size-fractionated primary productivity experiments were used to calculate carbon-specific growth rates. Growth rate estimates ranged from $0.9 \mathrm{~d}^{-1}$ at the center of a warm core eddy, to $8.9 \mathrm{~d}^{-1}$ in an upwelling region off $S$. W. Nova Scotia, Canada.
\end{abstract}

\section{INTRODUCTION}

A rapidly growing literature points to the abundance of very small photosynthetic microorganisms in the world ocean (e.g. Waterbury et al., 1979; Johnson and Sieburth, 1979, 1982; Li et al., 1983). The term picoplankton' has been suggested for organisms falling in the size range of 0.2 to $2.0 \mu \mathrm{m}$ (Sieburth et al., 1978). Dynamical measurements of phototrophs within this size range have confirmed that these microorganisms contribute substantially to the primary productivity of tropical, oligotrophic, and coastal eutrophic regions ( $\mathrm{Li}$ et al., 1983; Platt et al., 1983; Larsson and Hagström, 1982).

One problem in quantifying the abundance of these autotrophic cells is in differentiating them unequivocally from the heterotrophic bacterioplankton of similar size. To date, estimates of numbers of photosynthetic picoplankton in natural water samples have been based on morphology, ultrastructure (e.g. thylakoid arrangement), and fluorescence characteristics (Johnson and Sieburth, 1979; Waterbury et al., 1979). Probably the most widely used method for detection consists of counting cells using autofluorescence. This refers to the ability of some cells to fluoresce under epifluorescent illumination in much the same way as cells stained with fluorochromes (e.g. acridine orange, proflavin, and DAPI). This fluorescence is presumed to be due to the presence of photosynthetic pigments including chlorophyll and phycoerythrin.

As well as counts of individual cells, fluorescence measurements of acetone extracts of size fractionated water samples have been used to assess the abundance of these organisms (Li et al., 1983; Platt et al., 1983). The results of these workers have confirmed that a substantial portion of the total photosynthetic pigments in the tropical ocean may occur in the picoplankton size range.

This report presents a methodology for detection and enumeration of photosynthetic picoplankton based upon uptake of $\mathrm{H}^{14} \mathrm{CO}_{3}$ in the light. This technique couples autoradiography with epifluorescent microscopy to allow enumeration based on the trophic function of the cells. The technique was used to identify phototrophic cells based on exposure of silver grains due to light-dependent uptake of ${ }^{14} \mathrm{CO}_{3}$. While grain autoradiography may be a powerful tool for detection of cells involved in uptake of specific substrates, it is not appropriate for quantitative analysis of uptake by individual cells (Knoechel and Kalff, 1976). For this reason no attempt was made to compare relative rates of uptake by individual cells.

The cell numbers obtained with this technique have been combined with productivity measurements made 
on size-fractionated samples to estimate carbonspecific growth rates. This protocol has been followed at 5 stations off the coast of Nova Scotia. These stations were selected to test the reliability and reproducibility of the method over a range of environments.

\section{MATERIALS AND METHODS}

\section{Autoradiography}

Water samples were collected at 5 stations (Fig. 1), during the period June 2-11, 1982 on the C.S.S. Dawson' (Fig. 1). Five-liter Niskin bottle casts were collected at the $50 \%$ light level. Subsamples were placed

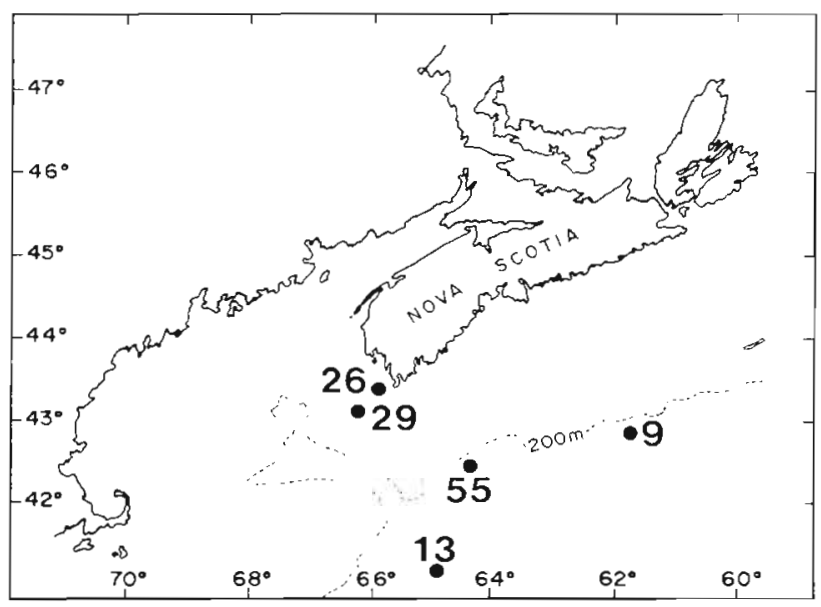

Fig. 1. Sampling locations

in $50 \mathrm{ml}$ glass bottles and inoculated with $50 \mu \mathrm{Ci}$ of Millipore HA filtered $\mathrm{NaH}^{14} \mathrm{CO}_{3}$ solution (New England Nuclear, specific activity: $0.1 \mathrm{mCi} \mathrm{mg}^{-1}$ ). This dosage is greater than that used in earlier work with larger phytoplankton (Maguire and Neill, 1971; Watt, 1971; Gutel'makher, 1973) and was chosen to maximize labelling of the picoplankton cells.

Except where otherwise noted, incubations were for $24 \mathrm{~h}$ in a simulated in situ incubator using flowthrough cooling and neutral-density light attenuating screens. Incubations were terminated with the addition of formalin to a final concentration of $2.0 \%$. An opaque bottle was included for each sample to test for dark uptake. Samples were stored at 2 to $4^{\circ} \mathrm{C}$ in the dark until processing in the laboratory.

Autoradiographic slides were prepared using a method adapted from a protocol described for heterotrophic bacteria by Meyer-Reil (1978). Several ml of each sample were filtered through a $0.2 \mu \mathrm{m}$ Nuclepore membrane which had been prestained for $48 \mathrm{~h}$ in Sudan Black (Sigma S-2380, $1: 15,000$ in $50 \%$ ethanol) The filters were then rinsed $(\times 5)$ with $10 \mathrm{ml}$ of Milli- pore $\mathrm{HA}$ filtered $3.0 \% \mathrm{NaCl}$ in distilled water and allowed to air dry. Wedge-shaped sections from the filters were attached to clean microscope slides using double sided adhesive tape (Scotch \# 665). The filter sections were placed across 2 strips of tape so that the membrane area to be viewed was not underlain by the tape. This is necessary as the tape absorbs stain causing a bright background fluorescence

The slides were dipped in photographic emulsion (Kodak NTB-2), diluted 1:3 with Millipore HA filtered water to produce an emulsion thickness of about $1 \mu \mathrm{m}$. After dipping, the ends of the slides were touched several times to a paper towel to draw off excess emulsion. The slides were then placed on an ice cold metal tray for at least $5 \mathrm{~min}$ to allow the emulsion to set. The slides were stored for ca. $12 \mathrm{~h}$ at room temperature in a desiccator and then transferred to light-tight boxes containing silica gel. They were allowed to expose for $21 \mathrm{~d}$ at 2 to $4{ }^{\circ} \mathrm{C}$. This exposure time was chosen on the basis of a preliminary experiment which confirmed that the number of cells labelled may increase for 18 to $20 \mathrm{~d}$ of exposure (Fuhrman and Azam, 1982).

After the exposure period, the slides were developed for 2 min (Kodak D-11, 1:3 in distilled water), rinsed briefly and fixed in $30 \%$ sodium thiosulfate. They were then rinsed for $20 \mathrm{~min}$ in distilled water.

The autoradiograms were soaked for $5 \mathrm{~min}$ in $\mathrm{pH} 6.6$ citrate buffer $(0.01 \mathrm{M}$, Sigma C-7254 citric acid trisodium salt and BDH ACS 231 citric acid monohydrate). They were then stained for $20 \mathrm{~min}$ in $0.1 \%$ acridine orange (Sigma No. 6014 dissolved in pH 6.6 citrate buffer). Destaining consisted of passing the slides through a series of citrate buffers as follows: pH 6.6, 5 min; pH 5.0, 3 min; pH 4.0, 3 min. The slides were then rinsed briefly in fresh $\mathrm{pH} 6.6$ buffer followed by distilled water. All solutions including developer fixer, stain, buffers, and rinse water were Millipore HA filtered immediately before use. All manipulations of undeveloped emulsion and slides were made in complete darkness

Controls for background silver grains were included as follows. To test for background grains arising from the emulsion itself, light, or grain exposure due to processing of the samples, a slide was included with a clean filter slice attached. A second set of controls was included to identify silver grains due to abiotic uptake of filtered cells. These consisted of filters with cells killed with formalin immediately following addition of the radiolabel.

Slides were viewed at $1250 \times$ magnification with an epifluorescence equipped (exciter filter, 450-490 nm; beam splitter, $510 \mathrm{~nm}$; suppression filter, $515 \mathrm{~nm}$ : Leitz filter pack I 2) Wild Leitz Dialux 20 EB microscope using oil (Cargille Type A) immersion. Cells were 
counted if they had exposed a minimum of three silver grains. In almost all cases more grains were exposed creating a 'halo' around the phototrophic cells (Fig. 2). Radiolabelled cells on 80 microscopic fields were counted for each sample. The mean cell abundance and the $95 \%$ confidence interval of the mean based on the counts are presented (Table 1). For fields with particularly dark backrounds, light was passed through the slides from the microscope condenser below. This increases contrast, improving visibility of the emulsion silver grains.

\section{Size-fractionated primary productivity measurements}

Along with each autoradiography sample a parallel sample was size-fractionated through a pre-rinsed $1.0 \mu \mathrm{m}$ Nuclepore membrane. These filtrations were by gravity (no applied vacuum) to minimize cell damage. The filtrate was then placed in $50 \mathrm{ml}$ glass bottles, inoculated with $\mathrm{H}^{14} \mathrm{CO}_{3}$, and incubated exactly as the autoradiography samples.

Whole water samples were also inoculated and incubated. These were fractionated following incubation using $1.0 \mu \mathrm{m}$ Nuclepore membranes and Millipore HA membranes for the $>1.0 \mu \mathrm{m}$ and $\leq 1.0 \mu \mathrm{m}$ fractions. These data form the basis of an ongoing study of the relative importance of heterotrophic uptake of the organic carbon produced by phytoplankton and are presented in this report only for comparison of the $\leq 1.0 \mu \mathrm{m}$ fraction uptake with total particulate uptake.

Duplicate light bottles and a single dark bottle were incubated for all productivity measurements. Productivity incubations were all of $24 \mathrm{~h}$ duration to correspond with those of autoradiography samples. Incubations were terminated by filtration of the samples onto Millipore HA filters followed by three rinses with filtered seawater. The filters were fumed over concentrated $\mathrm{HCl}$ to remove inorganic radiolabel. The radioactivity on the filter was counted using a LKB Rackbeta liquid scintillation counter. Quench correction was by external standards ratio and carbon uptake was calculated using the equation of Strickland and Parsons (1972).

\section{RESULTS}

\section{Autoradiography}

Samples collected at the $50 \%$ light level and incubated for $24 \mathrm{~h}$ produced autoradiographic preparations in which picoplankton cells were clearly labelled with silver grains (Fig. 2). Samples collected near the bottom of the euphotic zone and incubated at correspondingly lower light intensity produced autoradiograms in

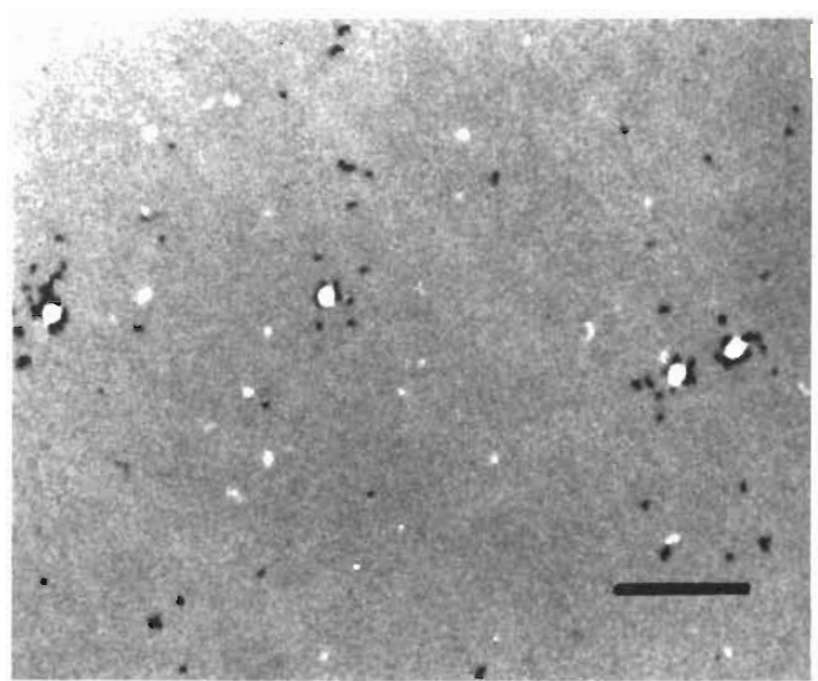

Fig. 2. Autoradiogram showing 4 labelled picoplankton cells (bar length $=5 \mu \mathrm{m}$ )

which a considerable proportion of cells were either unlabelled or had only 1 or 2 silver grains associated with them. Similarly, a preliminary experiment using a $6 \mathrm{~h}$ incubation produced inconclusive labelling of picoplankton cells. Based on these results, $24 \mathrm{~h}$ incubations of samples collected at the $50 \%$ light level were performed and are presented here.

Cell numbers of photosynthetic picoplankton ranged from 3.7 to $49 \times 10^{6}$ cells l$^{-1}$ (Table 1 ). The cells were

Table 1. Abundance, ${ }^{14} \mathrm{C}$ uptake, and specific growth rate of photosynthetic picoplankton

\begin{tabular}{|c|c|c|c|c|}
\hline $\begin{array}{c}\text { Station } \\
\text { No. }\end{array}$ & $\begin{array}{c}\text { Abundance } \\
\bar{X} \\
( \pm 95 \% \mathrm{CI})\end{array}$ & $\begin{array}{l}\mathrm{H}^{14} \mathrm{CO}_{3} \\
\text { uptake } \\
\text { ( } \pm \mathrm{CV})\end{array}$ & $\begin{array}{c}\% \% \\
<1.0 \mu \mathrm{m} \\
\text { uptake }\end{array}$ & $\begin{array}{l}\text { Specific } \\
\text { growth } \\
\text { rate }\end{array}$ \\
\hline 9 & $22.1( \pm 3.4)$ & $4.33( \pm 2.6 \%)$ & 65.1 & 3.1 \\
\hline 13 & $41.8\{ \pm 4.1\}$ & $2.40( \pm 15.7 \%)$ & 29.7 & 0.9 \\
\hline 26 & $3.7( \pm 1.3)$ & $1.88^{\circ}$ & 12.7 & 8.0 \\
\hline 29 & $5.8( \pm 1.4)$ & $3.28( \pm 8.8 \%)$ & 20.0 & 8.9 \\
\hline 55 & $49.5( \pm 6.1)$ & $5.81( \pm 13.4 \%)$ & 19.9 & 1.9 \\
\hline \multicolumn{5}{|c|}{$\begin{array}{l}\text { Units: Labelled cells, } \times 10^{6} \mathrm{l}^{-1} ; \mathrm{H}^{19} \mathrm{CO}_{3} \text { uptake, } \mu \mathrm{g} \mathrm{C \textrm {Cl } ^ { - 1 }} \\
\mathrm{d}^{-1} \text {, Specific growth rate, } \mathrm{d}^{-1} \\
\text { " Replicate sample lost }\end{array}$} \\
\hline
\end{tabular}

spherical or ovoid and ranged from approximately 0.8 to $1.4 \mu \mathrm{m}$ in maximum dimension. They were distinguishable from the majority of heterotrophic bacterioplankton, as determined using autoradiographic analysis of parallel samples incubated with the amino acid glutamate (Douglas, unpubl.), as the phototrophs tended to be both larger and produce brighter microscopic images (Fig. 2). This brightness is probably due, at least in part, to fluorescence of the photosynthetic pigments. 
At each of 2 stations (Sta. 9 and 55) one aggregate of phototrophs was observed. These clumps of cells had no distinguishable structure nor did they appear to comprise a substantial fraction of the cells within either of these 2 samples. In addition to picoplanktonsize cells, some diatoms, dinoflagellates and small pigmented flagellates were also present. Those from light incubations were strongly labelled with silver grains.

No cells were labelled in dark bottle incubations (dark bottle ${ }^{14} \mathrm{C}$ uptake averaged less than $5 \%$ of light uptake in the size fractionated productivity experiments) nor were any cells labelled in control bottles.

\section{Size fractionated ${ }^{14} \mathrm{C}$ uptake experiments}

The results of the $\mathrm{H}^{14} \mathrm{CO}_{3}$ uptake experiments on $1.0 \mu \mathrm{m}$ size fractionated water samples are presented in Table 1. These values have had dark bottle uptake subtracted from them and range from 1.88 to $5.81 \mu \mathrm{g} \mathrm{C}$ $\mathrm{l}^{-1} \mathrm{~d}^{-1}$. The values are presented (Table 1) with the coefficient of variation from the results of duplicate light bottle incubations. These are based on a $24 \mathrm{~h}$ incubation and have not been corrected for daylight length.

The proportion of total particulate uptake which was due to photosynthesis of the $\leq 1.0 \mu \mathrm{m}$ size fraction was calculated as:

$\%$ Uptake $=\frac{\leq 1.0 \mu \mathrm{m} \text { uptake }}{\leq 1.0 \mu \mathrm{m} \text { uptake }+>1.0 \mu \mathrm{m} \text { uptake }} \times 100$

This fraction ranged from 12.7 to $65.1 \%$, with a mean of $29.5 \%$ (Table 1 ).

\section{Growth rates}

Based on the results of the autoradiographic preparations in this study as well as previous work (e.g. Li et al., 1983), the phototrophic cells can be closely approx- imated by assuming an average diameter of $1.0 \mu \mathrm{m}$ Phototrophic cell carbon estimates have been made using this approximation and a cell volume to carbon

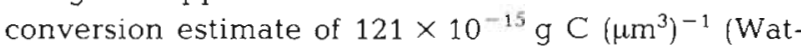
son et al., 1977). The carbon-specific growth rates have been calculated for these samples using the relation:

Specific growth rate $=\frac{\text { Carbon uptake }\left(\mu \mathrm{g} \mathrm{C} \mathrm{l}^{-1} \mathrm{~d}^{-1}\right)}{\text { Cell carbon }\left(\mu \mathrm{g} \mathrm{C}^{-1}\right)}$

The results of these calculations are presented in Table 1,

\section{DISCUSSION}

The autoradiography technique allows unambiguous differentiation between the very small photoautotrophs and heterotrophic bacteria. It has proven reliable and relatively straightforward, making it a valuable tool for routine analysis of field samples. The method has the advantage that all cells are viewed rather than a subsample which are transferred by the method recently published by Tabor and Neihof (1982; see also Fuhrman and Azam, 1982).

The morphology of the cells which incorporated $\mathrm{H}^{14} \mathrm{CO}_{3}$ in the light corresponds closely to that described for chroococcoid cyanobacteria. This method does not, however, allow the resolution required for taxonomic differentiation. These results, then, do not preclude the possibility that microscopic eukaryotic cells such as those reported by Johnson and Sieburth (1982) and Wilhelm et al. (1982) are also present in the photosynthetic picoplankton.

Perhaps most importantly, the consistant morphology of these cells, coupled with their light dependent ${ }^{14} \mathrm{CO}_{2}$ uptake in samples size-fractionated prior to incubation (removing organisms greater than $1.0 \mu \mathrm{m}$ ) eliminates the possibility that these are simply radiolabelled fragments of larger cells.

Cell abundance of photosynthetic picoplankton reported in the literature ranges over several orders of

Table 2. Picoplankton cell numbers cited in recent literature

\begin{tabular}{|lll|}
\hline $\begin{array}{c}\text { Picoplankton } \\
\text { abundance }\end{array}$ & Location & Reference \\
\hline $4.4-17$ & Azores & Platt et al. (1983) \\
$500-1500$ & Costa Rica Dome & Li et al. (1983) \\
1.08 & Narragansett Bay & Johnson and Sieburth (1979) \\
0.3 & Rhode Island shelf & Johnson and Sieburth (1979 \\
$4.8-125$ & Peru and Arabian Sea & Waterbury et al. (1979) \\
1.3 & Slope water & Waterbury et al. (1979) \\
$2.0-360$ & Woods Hole Harbor & Waterbury et al. (1979) \\
$3.7-49.5$ & Coastal, slope and eddy & Present study \\
- Units: cells $\times 10^{6} l^{-1}$ & & \\
\hline
\end{tabular}


magnitude (Table 2). Subjectivity in counting cells using autofluorescence may contribute somewhat to this variability. However, even within a single location, variation has been reported to be as great as 180 times over a 1 mo sampling period (Waterbury et al., 1979).

Comparison of the results of the present study with cell numbers cited in the literature show these to fall in the middle for the values cited but towards the upper range for coastal environments (with the exception of Woods Hole Harbor; Waterbury et al., 1979). These results also support the general pattern of lower numbers of these organisms in coastal regions (i.e. Sta. 26 and 29) relative to offshore stations. More detailed analysis of differences between stations is probably not warranted; the sampling program was designed to test the reliability of this technique over a range of environmental conditions rather than to provide extensive distributional data on abundance of picoplankton cells.

${ }^{14} \mathrm{C}$ uptake of the $\leq 1.0 \mu \mathrm{m}$ size fraction, relative to total uptake, ranged from 12.7 (Sta. 26) to $65.1 \%$ (Sta. 9). The values reported here are lower than those measured for tropical oceans (ca. 40 to $85 \%$ : Li et al., 1983 ; $60 \%$ : Platt et al., 1983) but point to a sizable contribution from these cells to total productivity in coastal and slope regions.

The growth rates of the organisms which make up the phototrophic picoplankton are almost entirely unknown. Laboratory work on 2 strains of the cyanobacterium Synechococcus has revealed optimal growth rates of 1.85 and $2.18 \mathrm{~d}^{-1}$ (Morris and Glover, 1981). Estimates of growth rates of natural assemblages in the oligotrophic ocean, based on size-fractionated particulate organic carbon and ${ }^{14} \mathrm{C}$ incorporation measurements, were $0.15 \mathrm{~d}^{-1}$ (Platt et al., 1983). These workers noted that faster growth rates were calculated when cell carbon was estimated directly from cell numbers.

In the present study, growth rates were estimated using ${ }^{14} \mathrm{C}$ uptake and cell carbon estimates based on autoradiographic cell counts. The growth rates calculated for the picoplankton ranged from a low of $0.9 \mathrm{~d}^{-1}$ in a relatively oligotrophic warm core eddy to $8.9 \mathrm{~d}^{-1}$ in a region characterized by upwelling and relatively high chlorophyll concentrations (Garrett and Loucks, 1976; Fournier et al., 1983). These growth rates are clearly greater than those reported in the literature. This is the case particularly for the 2 stations off S.W. Nova Scotia (Sta. 26 and 29). Both stations were characterized by low abundance of picoplankton cells but not by correspondingly lower ${ }^{14} \mathrm{C}$ uptake rates in the $\leq 1.0 \mu \mathrm{m}$ size fraction.

A possible source of error in the ${ }^{14} \mathrm{C}$ uptake estimates stems from the use of $24 \mathrm{~h}$ incubations. Recently there has been evidence accumulating of problems associated with conventional methods of measuring productivity using ${ }^{14} \mathrm{C}$. These include errors due to effects of containment and to non-linear uptake of radiolabelled carbon by natural marine phytoplankton incubated for periods of several hours (e.g. Gieskes et al., 1979; Goldman et al., 1981; Li and Harrison, 1982). Generally, however, long-term incubations give lower rates of production than do short-term ones (Carpenter and Lively, 1980). On this basis, the uptake rates presented in this report should be considered as conservative

If photosynthetic picoplankton are as substantial in both abundance and productivity as is indicated by the results of this and other recent studies, models of the structure of marine ecosystems will clearly require modification to encompass this source of fixed carbon. As well as dynamic measurements of the picoplankton themselves, there is also an immediate need to identify both their grazers and the rates at which they are taken. The autoradiographic technique described in this paper may prove valuable in the identification of those grazers as it has in the demonstration of autotrophy in the picoplankton.

Acknowledgements. I thank Drs. R. O. Fournier, $\Upsilon$ Platt, and $J$. Novitsky for critical comments on an earlier draft of this manuscript. This work was supported by grants A-6751 (R. O.F.) and A-0593 (J. S. Wroblewski) from the Natural Sciences and Engineering Research Council of Canada

\section{LITERATURE CITED}

Carpenter, E. J., Lively, J. S. (1980). Review of estimates of algal growth using ${ }^{14} \mathrm{C}$ techniques. In: Falkowski, P. G. (ed.) Primary productivity in the sea. Plenum Press, New York, p. 161-178

Fournier, R. O., Van Det, M., Hargreaves, N. B., Wilson, J. S., Clair, T. A., Ernst, R. (1983). Physical factors controlling summer distributions of chlorophyll a off southwestern Nova Scotia. Limnol. Oceanogr (In press)

Fuhrman, J. A., Azam, F. (1982). Thymidine incorporation as a measure of heterotrophic bacterioplankton production in marine surface waters: evaluation and field results. Mar. Biol. 66: 109-120

Garrett, C. J. R., Loucks, R. H. (1976). Upwelling along the Yarmouth Shore of Nova Scotia. J. Fish. Res. Bd Can. 33: 2213-2217

Gieskes, W. W. C., Kraay, G. W., Baars, M. A. (1979). Current ${ }^{14} \mathrm{C}$ methods for measuring primary production: gross underestimates in oceanic waters. Neth. J. Sea. Res. 13: $58-78$

Goldman, J. C., Taylor, C. D., Glibert, P. M. (1981). Nonlinear time-course uptake of carbon and ammonium by marine phytoplankton. Mar. Ecol. Prog. Ser. 6: 137-148

Gutel'makher, B. L. (1973). Autoradiography as a method of determining the relative contribution of individual algal species to the primary production of plankton. Hydrobiol. J. 9: $61-64$ 
Johnson, P. W., Sieburth, J. McN. (1979). Chroococcoid cyanobacteria in the sea: a ubiquitous and diverse phototrophic biomass. Limnol. Oceanogr. 24: 928-935

Johnson, P. W., Sieburth, J. McN. (1982). In-situ morphology and occurrence of eukaryotic phototrophs of bacterial size in the picoplankton of estuarine and oceanic waters. J. Phycol. 18: 318-327

Knoechel, R., Kalff, J. (1976). The applicability of grain density autoradiography to the quantitative determination of algal species production: a critique. Limnol. Oceanogr. 21: $583-590$

Larsson, U., Hagström, $\AA$. (1982). Fractionated phytoplankton primary production, exudate release and bacterial production in a Baltic eutrophication gradient. Mar. Biol. 67: $57-70$

Li, W. K. W., Harrison, W. G. (1982). Carbon flow into the endproducts of photosynthesis in short and long incubations of a natural phytoplankton population. Mar. Biol. 72: $175-182$

Li, W. K. W., Subba Rao, D. V., Harrison, W. G., Smith, J. C., Cullen, J. J., Irwin, B., Platt, T. (1983). Autotrophic picoplankton in the tropical ocean. Science, N. Y. 219: 292-295

Maguire, B. Jr., Neill, W. E. (1971). Species and individual productivity in phytoplankton communities. Ecology 52: 903-907

Meyer-Reil, L.-A. (1978). Autoradiography and epifluorescence combined for the determination of number and spectrum of actively metabolizing bacteria in natural waters. Appl. environ. Microbiol. 36: 506-512
Morris, I., Glover, H. (1981). Physiology of photosynthesis by marine coccoid cyanobacteria-Some ecological implications. Limnol. Oceanogr 26: 957-961

Platt, T., Subba Rao, D. V., Irwin, B. (1983). Photosynthesis of picoplankton in the oligotrophic ocean. Nature, Lond. 301: $702-704$

Sieburth, J. McN., Smetacek, V., Lentz, J. (1978). Pelagic ecosystem structure: heterotrophic compartments of the plankton and their relationship to plankton size fractions. Limnol. Oceanogr. 23: 1256-1263

Strickland, J. D. H., Parsons, T. R. (1972). A practical handbook of seawater analysis. Fisheries Research Board of Canada, Ottawa

Tabor, P. S., Neihof, R. A. (1981). Improved microautoradiographic method to determine individual microorganisms active in substrate uptake in natural waters. Appl. environ. Microbiol. 44: 945-953

Waterbury, J. B., Watson, S. W., Guillard, R. R. W., Brand, L. E. (1979). Widespread occurrence of a unicellular, marine, planktonic, cyanobacteria. Nature, Lond. 277: 293-294

Watson, S. W., Novitsky, T. J., Quinby, H. L., Valois, F. W (1977). Determination of bacterial number and biomass in marine environments. Appl environ. Microbiol. 33: 940-946

Watt, W. D. (1971). Measuring the primary production rates of individual phytoplankton species in natural mixed populations. Deep Sea Res. 18: 329-339

Wilhelm, C., Eisenbeis, G., Wild, A., Zahn, R. (1982). Nanochlorum eucaryotum: a very reduced coccoid species of marine chlorophycea. Z. Naturforsch. 37: 107-114

This paper was presented by Professor P. J. Wangersky; it was accepted for printing on August 5, 1983 